\title{
Article \\ Effects of Wollastonite on Fire Properties of Particleboard Made from Wood and Chicken Feather Fibers
}

\author{
Hamid R. Taghiyari ${ }^{1, *\left(\mathbb{D}, \text { Holger Militz }^{2}\left(\mathbb{D}, \text { Petar Antov }^{3}(\mathbb{D}) \text { and Antonios N. Papadopoulos }\right.\right.}{ }^{4, *(\mathbb{D})}$ \\ 1 Wood Science and Technology Department, Faculty of Materials Engineering \& New Technologies, \\ Shahid Rajaee Teacher Training University, Tehran 16788-15811, Iran \\ 2 Wood Biology and Wood Products, Georg-August-University Göttingen, 37077 Göttingen, Germany; \\ hmilitz@gwdg.de \\ 3 Faculty of Forest Industry, University of Forestry, 1797 Sofia, Bulgaria; p.antov@ltu.bg \\ 4 Laboratory of Wood Chemistry and Technology, Department of Forestry and Natural Environment, \\ International Hellenic University, GR-661 00 Drama, Greece \\ * Correspondence: htaghiyari@sru.ac.ir (H.R.T.); antpap@for.ihu.gr (A.N.P.)
}

check for updates

Citation: Taghiyari, H.R.; Militz, H.; Antov, P.; Papadopoulos, A.N. Effects of Wollastonite on Fire Properties of Particleboard Made from Wood and Chicken Feather Fibers. Coatings 2021, 11, 518. https://doi.org/10.3390/ coatings11050518

Academic Editor: Salim Hiziroglu

Received: 9 April 2021

Accepted: 27 April 2021

Published: 28 April 2021

Publisher's Note: MDPI stays neutral with regard to jurisdictional claims in published maps and institutional affiliations.

Copyright: (c) 2021 by the authors. Licensee MDPI, Basel, Switzerland. This article is an open access article distributed under the terms and conditions of the Creative Commons Attribution (CC BY) license (https:/ / creativecommons.org/licenses/by/ $4.0 /)$.

\begin{abstract}
The present study was carried out primarily to investigate the fire properties of particleboards with $5 \%$ and $10 \%$ feather content. With regard to the flammability of chicken feathers, separate sets of panels were produced with $10 \%$ wollastonite content to determine to what extent it could help mitigate the negative effects of the addition of flammable feathers on the fire properties. It was concluded that the inclusion of $5 \%$ of chicken feathers can be considered the optimum level, enough to procure part of the ever-growing needs for new sources of raw material in particleboard manufacturing factories, without sacrificing the important fire properties. Moreover, the addition of $10 \%$ wollastonite is recommended to significantly improve the fire properties, making the panels more secure in applications with higher risks of fire. It is further stated thata chicken feather content of $10 \%$ is not recommended as it significantly deteriorates all properties (including physical, mechanical, and fire properties).
\end{abstract}

Keywords: fire-retarding property; particleboard; piloted flame; wollastonite; wood-based composite

\section{Introduction}

Wood and wood-based composites are susceptible to abiotical and biological decay by fungi, insects, and fire; therefore, over the years many methods, preservatives, and fire retardants have beenused to help mitigate these drawbacks [1-6]. The history of fire retardants goes back to applying inorganic salts many years ago. It was only in the last century that solid wood was pressure-impregnated with fire retardants [7-10]. Based on this, a new set of building codes emerged, known as Fire Retardant Treated (FRT) Lumber. These codes can be applied to both solid wood species and wood-based building materials. Some chemicals used in FRT Lumber increase the threshold temperature at which thermal degradation occurs $[11,12]$. This process is translated into a reduction in both the amount of char produced during the process of burning as well as the amount offlammable volatiles. There are other newly developed materials that have used the heattransferring properties of some mineral and metal materials to prevent the accumulation of heat at one spot, andtherefore the ignition of wood or wood-based composite panels can be significantly delayed $[5,6,9,13]$. One of these new fire retardants is sepiolite. It is a natural hydrous mineral with unique properties whichhasshown to be effective in improving thermal conductivity in oriented-strand lumber production and in the fire retardancy of solid wood [14,15]. Graphene is another newlydeveloped fire retardant; it consists of a one-atom-thick planar sheet, in which carbon atoms are hexagonally arranged, and it is therefore considered a nano-material. These sheets are densely packed in a honeycomb crystal lattice. Graphene has receivedappreciable attention over the last two decades due to its special structure and exceptional properties [16]. 
Traditionally, three vital perspectives were taken into consideration for a chemical to be used as a fire retardant: the kind and amount of toxic gases that are produced, the extent to which the mechanical properties are reduced, and its effects on the hygroscopicity $[17,18]$. Although all of these perspectives have been elaborated over the years, environmental and health concerns have only recently been taken into consideration. In this regard, wollastonite has been proved to cause no health hazards to either humans or wildlife $[19,20]$, it is a silicate material $\left(\mathrm{CaSiO}_{3}\right)$ with no chemical pollution, and it does not have any negative effects on mechanical properties as it does not have any acidic chemicals $[5,6,13,21]$. Its application in wood-based composites is simple, as it can be physically mixed with resin and sprayed on the furnish. There are many wollastonite mines all over the world and, therefore, the cost of production would be economical inregards to the benefits it adds to wood-based composite panels $[5,6,13,21]$. Other silicate materials that are currently used in wood-based panels industry include:

(i) Nanoclays(layered aluminosilicates). It has been reported that montmorillonite, a variety of bentonite clays, is the most effective and promising among layered silicates. Its main characteristic is its ability to split into individual nanosized plates [22].

(ii) Nano-oxides. Nanoparticles of titanium have been applied for this purpose [23]. They create a fire retardant barrier on wood surfaces which retard flame spread and suppress smoke generation. Additionally, during the fire, they produce water and gases which provide a cooling effect by snuffing out the oxygen. At the same time, char is created, which in turn protects the wood surface from combustion [24]. Another nano-oxide with promising potential is $\mathrm{ZnO}$ [25].

(iii) Nanosilicasol and silicon compounds. Nano- $\mathrm{SiO}_{2}$ was impregnated into the wood by the sol-gel method and demonstrated great potential [26].

(iv) Nanostructured carbon materials. The information oncarbon nanotubes and graphenes as potential materials for fire retardants is limited.

From another perspective, the wood-based composite industry is in constant demand for raw materials. Therefore, different sources of natural and synthetic materials other than wood and ligno-cellulose materials have been studied to keep pace with the evergrowing demand for raw materials. A variety of plants have been studied and tested worldwide in composites manufacturing, including vine stalks [27], topinambur stalks [28], cotton stalks [29], bamboo and coconut chips [30,31], canola straws [32], oil palms and poppy husks [33], rice and wheat straw [34], vine prunings [35], castor stalks [36], flax and banana chips [37,38], cotton stalks [39], and even seaweeds [40]. Chicken feathers were reported to be a low-cost option to be used partially, along with wood chips and fibers [21,41-43]. The physical and mechanical properties of medium-density fiberboard (MDF) and particleboard panels produced with a proportion of chicken feathers were promising. Moreover, wood-based panels with small proportions of chicken feathers would have the potential to produce lighter panels, with adequate thermal properties (acceptable thermal conductivity values, based on the value $\lambda<1.15 \mathrm{~W} / \mathrm{m} * \mathrm{~K}$ which is considered to be the limit for an appropriate insulation material). All these aspects are still to be carefully examined and, therefore, the present study was carried out primarily to investigate the fire properties of particleboards with $5 \%$ and $10 \%$ feather contents. With regard to the flammability of chicken feathers, separate sets of panels were produced with $10 \%$ wollastonite content to determine to what extent it could help mitigate the negative effects of the addition of flammable feathers on the fire properties.

\section{Materials and Methods}

\subsection{Panel Production and Specimen Preparation}

Wood chips were purchased from Shahid Dr. Bahonar Composite-board Company (Gorgancity, Iran) to produce particleboards. The chips consisted of a mixture of different species, namely beech (Fagusorientalis), alder (Alnusglutinosa), maple (Acer hyrcanum), hornbeam (Carpinusbetulus), and poplar (mostly Populusnigra) species from local forests (Amol, Iran), with the addition of $5 \%-7 \%$ pruning branches of the fruit gardens. Boards 
were produced with a target thickness of $16 \mathrm{~mm}$ and $0.67 \mathrm{~g} / \mathrm{cm}^{3}$ density; density was kept constant for all treatments. Urea-formaldehyde (UF) resin content was $10 \%$ based on the dry weight of wood chips, or the mixture of wood chips and feathers. The viscosity of the resin was $200-400 \mathrm{mPa}$ s, with a $47 \mathrm{~s}$ gel time, and $1.277 \mathrm{~g} / \mathrm{cm}^{3}$ density. The producer of UF resin was Pars Chemical Industries (Tehran, Iran). The resin was sprayed on the wood chips, or the mixture of wood chips and chicken feathers, in a laboratory rotary drum. The furnish was then pressed for six minutes in a hot press, the specific platen pressure of which was $16 \mathrm{MPa}$. The dimension of the platens was $700 \mathrm{~mm} \times 700 \mathrm{~mm}$. The temperature of the hot press was $175^{\circ} \mathrm{C}$. Spacers, made of alloy steel $16 \mathrm{~mm}$ in thickness, were used on the right and left sides of panels to prevent over-pressing the furnish, and to make sure the thickness of all panels was the same.

Five replicate panels were produced for each of the six treatments. The dimensions of all panels were $450 \mathrm{~mm} \times 450 \mathrm{~mm} \times 16 \mathrm{~mm}$. Five centimeters around the sides of all panels were trimmed. From each panel, two specimens were cut for each physical and mechanical test. Once cut, all specimens were conditioned for eight weeks $\left(25^{\circ} \mathrm{C}\right.$, and $40 \pm 3 \%$ relative humidity) before fire tests were carried out on them. The moisture content of specimens was $7.5 \pm 0.5 \%$ at the time of testing [44].

Serine $\left(\mathrm{C}_{3} \mathrm{H}_{7} \mathrm{NO}_{3}\right)$ is the main ingredient of bird feathers. The chicken feathers were procured from a commercial chicken farm. The feathers were first washed with water containing no detergent. The separation of feather fibers from quills is expensive and elevates the production costs to a degree that wouldnot be beneficial from an industrial point of view. Therefore, only the feathers from the body of the chickens were used; the quills in body feathers are not very thick and so are flexible enough to be used without the costly process of separation.

\subsection{Wollastonite Application}

Wollastonite gel was purchased from Mehrabadi Technology Company (Tehran, Iran). The chemical composition of this mineral material was the same as that previously used by Taghiyari et al. $[13,16]$. More than $90 \%$ of the wollastonite particles ranged from 1 to $4 \mu \mathrm{m}$ in width and thickness, and from 5 to $25 \mu \mathrm{m}$ in length. Based on the dry weight of the UF resin used, $10 \%$ of the wollastonite (dry weight basis) was added to the resin to be mixed using a magnetic stirrer for twenty minutes. The mixture was then sprayed on wood chips or on the mixture of wood chips and feathers in a rotary drum.

\subsection{Fire-Retardant Testing Device}

The idea was brought up to design and build a simple, low-cost device to carry out preliminary tests, by means of piloted ignition [6,21]. A slide fire test apparatus (SFTA) is placed in a three-wall compartment so that the burning flame is not disturbed by the movement of surrounding air. Natural gas (mainly methane $\mathrm{CH}_{4}, 90 \%-98 \%$ ) is burnt through a Bunsen-type burner (with an internal diameter of $11 \mathrm{~mm}$ ); the burner is held at 45 degrees to the specimen for $120 \mathrm{~s}$ (based on requirements of standard ISO 11925-3) [45]. During the test, the times at the onset of ignition and glowing at the point closest to the piloted ignition are registered. Once the specimen has been exposed to the piloted flame for the required time (in the present study, 120 s), the slide on which the Bunsen burner is mounted is pulled back. The duration of time that a visible flame can be observed on specimens is registered as the duration of burning. The length and width of the burnt area are also measured once the specimen is cooled off.

\subsection{Statistical Analysis}

Two-way analysis of variance (ANOVA) was carried out using the Statistical Package for Social Sciences (SPSSversion 18; 2010) for each and every fire property, to ascertain significant differences between the existing groups and treatments at the $95 \%$ level of confidence. Hierarchical cluster analysis was performed by SPSS (version 18; 2010) to 
categorize treatments based on the five fire properties tested in this study. Contour and surface plots were designed using Minitab statistical software (version 16.2.2; 2010).

\section{Results and Discussion}

Results demonstrated a statistically significant difference between the treatments ( $p$-value of 0.000). The lowest and highest times to the onset of ignition were observed in the panels with $10 \%$ feather content (PB-CF10\%, 38 s) and wollastonite and $10 \%$ feather content (PB-W-CF10\%, $63.7 \mathrm{~s}$ ), respectively (Figure 1). The addition of chicken feathers had a significant unfavorable decreasing effect on the time to the onset of ignition. This was partially attributed to the flammable nature of chicken feathers. The addition of chicken feathers was reported to have nearly the same decreasing effect on medium-density fiberboard panels [22]. Moreover, the incompatibility of chicken feathers, as a hydrophobic keratin material [41], to a woody cell wall resulted in a low integration between wood chips and feather fibers. This was also partially instrumental in the significant decrease in the time to the onset of ignition in the panels with both feather contents of $5 \%$ and $10 \%$.

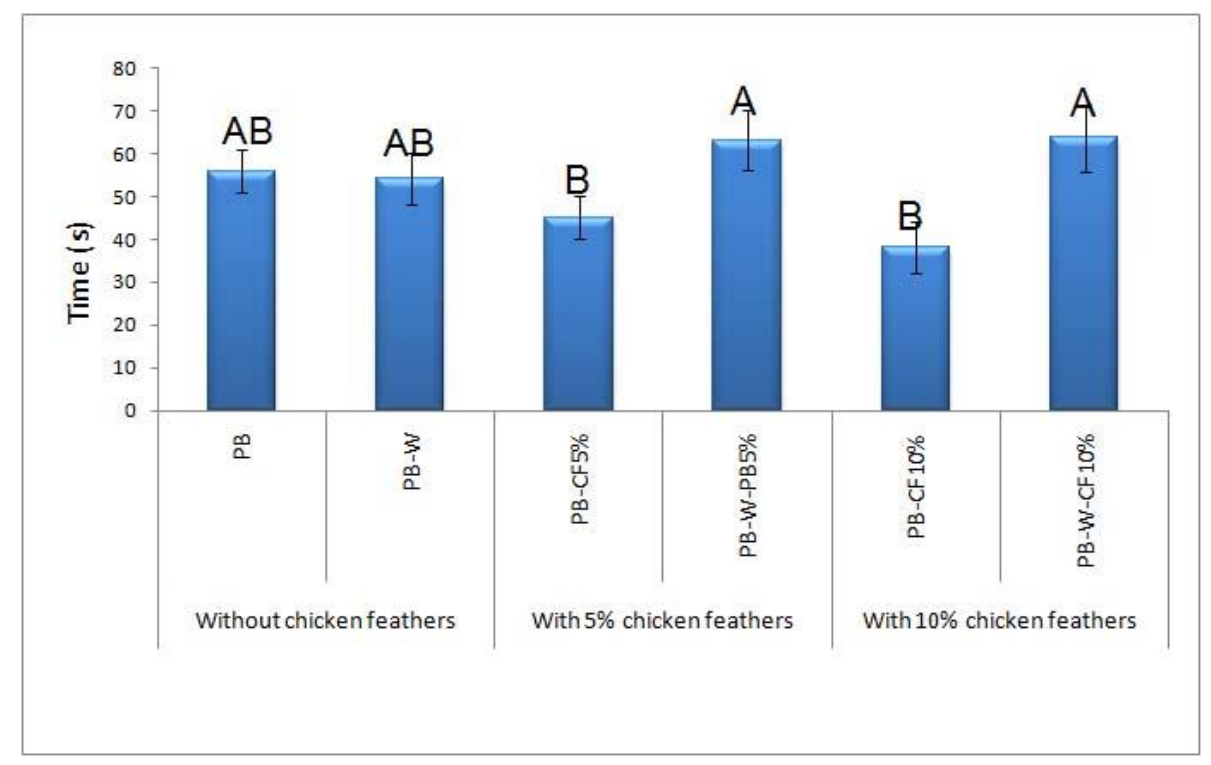

Figure 1. Time to the onset of ignition (in seconds) in six particleboard panels made from wood chips and the two chicken feather contents of $5 \%$ and $10 \%$, containing $10 \%$ wollastonite $(\mathrm{PB}=$ particleboard panels; $\mathrm{W}=$ panels containing wollastonite; $\mathrm{CF}=$ chicken feather content) (letters on each column bar represent groupings based on Duncan's multiple range test, $\alpha=0.05$ ).

The addition of wollastonite resulted in no significant alteration in the time to the onset of ignition in the panels with no chicken feather content. This was quite opposite to what was studied in MDF panels previously, in which a significant and favorable increase in the time to the onset of ignition was reported [46]. In order to explain this, the mechanical properties of the two kinds of composite panels (MDF and particleboard) should also be taken into consideration. A previous study on the effects of the addition of wollastonite on the physical and mechanical properties of MDF and particleboard panels reported an increasing effect in modulus of rupture (MOR) in MDF panels, and no significant effect in particleboard panels [21]. This clearly illustrated that the effects of the addition of wollastonite on MOR and the time to the onset of ignition in the two types of panels (MDF and particleboard) were quite in agreement. It was explained for MOR values that wollastonite reinforced the resin, and that fibers had more contact points in MDF panels in comparison to the wood particles in particleboards; moreover, the adsorption energy and adsorption distance of wollastonite on cell wall polymers were in favor of better integrity in the composite panels [47].Eventually, theMOR was significantly increased in MDF panels. The reinforcement of resin by the addition of other materials at micro- and nano-scales 
has also been reported $[48,49]$. Similarly, it can be concluded that the same reinforcing effect of wollastonite in the resin in MDF panels ultimately increased the time to the onset of ignition. However, in particleboard panels, the integrity of the wood chips was not as improved as the wood fibers in MDF panels; therefore, wollastonite could not significantly improve this fire property.

The addition of wollastonite significantly improved the time to the onset of ignition in panels containingchicken feathers (at both content levels of 5\% and 10\%) (Figure 1). Though the improvement was not statistically significant in comparison to the control panels (that is, the panels containing no wollastonite and no chicken feathers), the times were significantly higher in comparison to the panels with chicken feather contents of $5 \%$ and $10 \%$ and no wollastonite content. It can be concluded that wollastonite can be recommended in particleboard panels containing chicken feathers to mitigate the negative effects of the addition of feathers and to improve the time to the onset of ignition.

In terms of the time to the onset of glowing, the results demonstrated no significant difference among the six treatment panels, with a $p$-value of 0.992 (Figure 2). The panels produced in the present study were all single-layer panels; that is, the wood chips in the surface and core layers consisted of chips with the same size range. This in turn meant that larger-sized chips also appeared on a random basis in the surface layers. The mixture of resin and wollastonite was sprayed on the wood particles; this meant that wollastonite existed only on the surface of the wood particles. Therefore, it can be explained that once the piloted fire has gone past the surface of each particle, the untreated wood is exposed to fire. Contrary to particleboard panels, the previous study on MDF panels illustrated a significant increase in the time to the onset of glowing in wollastonite-treated panels. This was attributed to the smaller size of the wood fibers in MDF panels in comparison to the larger size of wood particles in particleboard panels. In fact, the piloted fire should have had to pass through repeated layers of wollastonite-treated surfaces; this eventually significantly increased the glowing time in wollastonite-treated MDF panels in comparison to their particleboard panel counterparts.

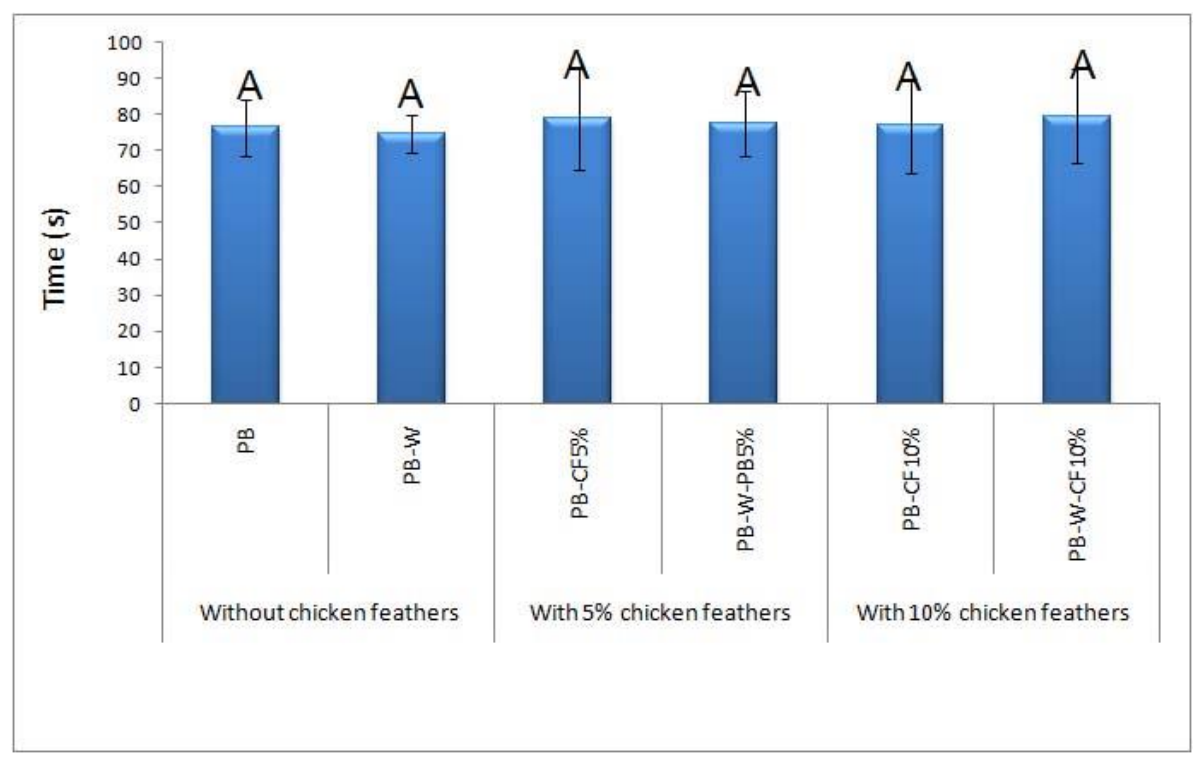

Figure 2. Time to the onset of glowing (in seconds) in six particleboard panels made from wood chips and the two chicken feather contents of $5 \%$ and $10 \%$, containing $10 \%$ wollastonite (PB = particleboard panels; $\mathrm{W}=$ panels containing wollastonite; $\mathrm{CF}=$ chicken feather content) (letters on each column bar represent groupings based on Duncan's multiple range test, $\alpha=0.05$ ).

The highest and lowest duration of burning occurred in the panels with the $10 \%$ chicken feather content and the control panels, respectively (Figure 3). The addition of wollastonite significantly decreased the duration of burning in the panels with no chicken 
feathers. However, no significant decrease was observedin panels withfeathers, though wollastonite tended to insignificantly decrease the duration of burning in the panels with the $10 \%$ chicken feather content. Wollastonite acted as an insulating layer, and it delayed the permeation of the fire to the inner layers; therefore, it could significantly decrease the duration of burning. In the panels with containingchicken feathers, a lack of integrity in the panels (as a result of the incompatibility of the chicken feathers with wood and UF resin) put the decreasing effect of wollastonite in perspective; eventually, no significant difference was observed.

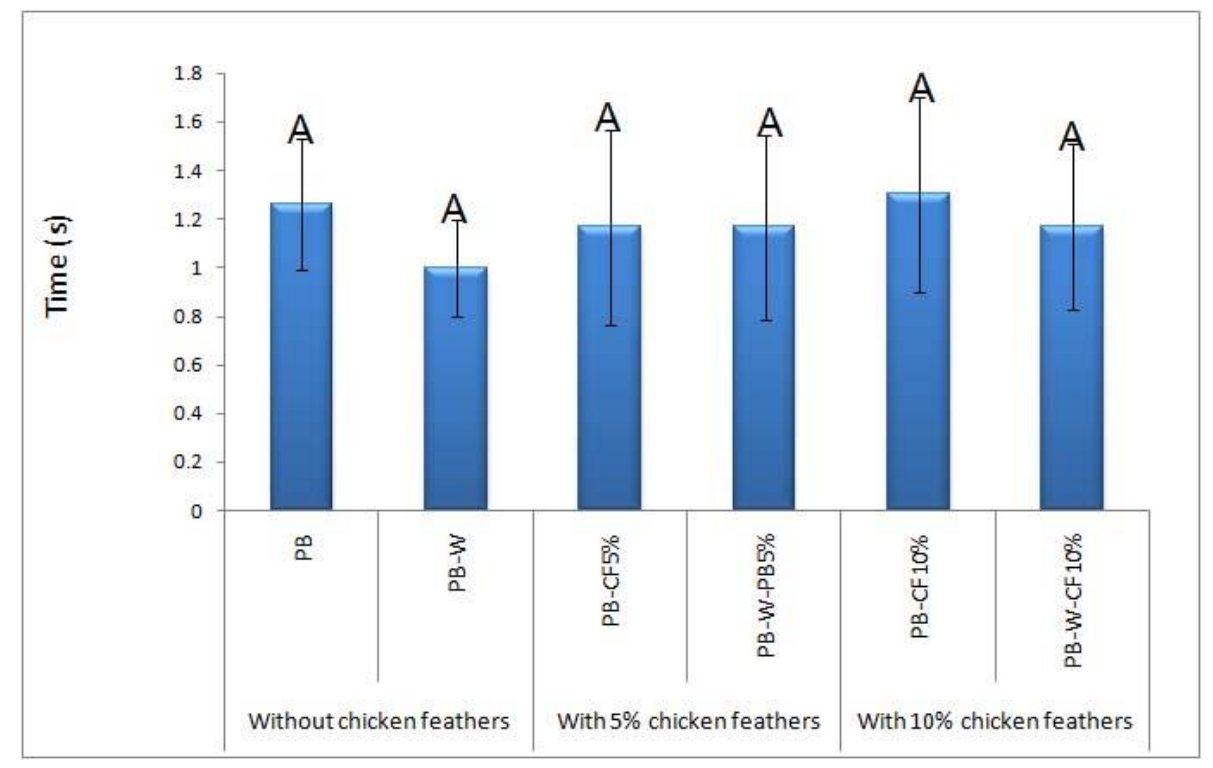

Figure 3. Duration of burning (in seconds) after the removal of piloted fire, in the six particleboard panels made from wood chips and the two chicken feather contents of $5 \%$ and $10 \%$, containing $10 \%$ wollastonite $(\mathrm{PB}=$ particleboard panels; $\mathrm{W}=$ panels containing wollastonite; $\mathrm{CF}=$ chicken feather content) (letters on each column bar represent groupings based on Duncan's multiple range test, $\alpha=0.05)$.

No significant difference was observed in either the length or the width of the burnt area, though slight insignificant fluctuations occurred in both properties with no particular trend (Figure $4 \mathrm{~A}, \mathrm{~B}$ ). In a previous study on the fire properties of particleboard with different wollastonite contents, a similar lack of impact of the wollastonite on the width of the burnt area was reported [50]. Moreover, there was no statistical grouping among different treatments, showing rather no particular trend. This can indicate that wollastonite cannot significantly improve these two properties in particleboard panels.

Previous studies on the relationship between fire properties reported a high and significant correlation between the different properties $[9,13]$. In the present study, however, the R-squared values between the fire properties were low and statistically insignificant. In this regard, though an overall relationship among the fire properties was observed, some inconsistencies in the general trend are also obvious in the contour and surface plots (Figure 5A,B). The inconsistencies in the graphs are attributed to the opposing effect, as well as the contradictory interaction, of wollastonite and chicken feathers on the fire properties. That is, wollastonite positively affected the properties, while the addition of chicken feathers resulted in the deterioration of properties. Eventually, these contradictory interactions resulted in the discrepancies in the general trend as illustrated in the contour and surface plots. 


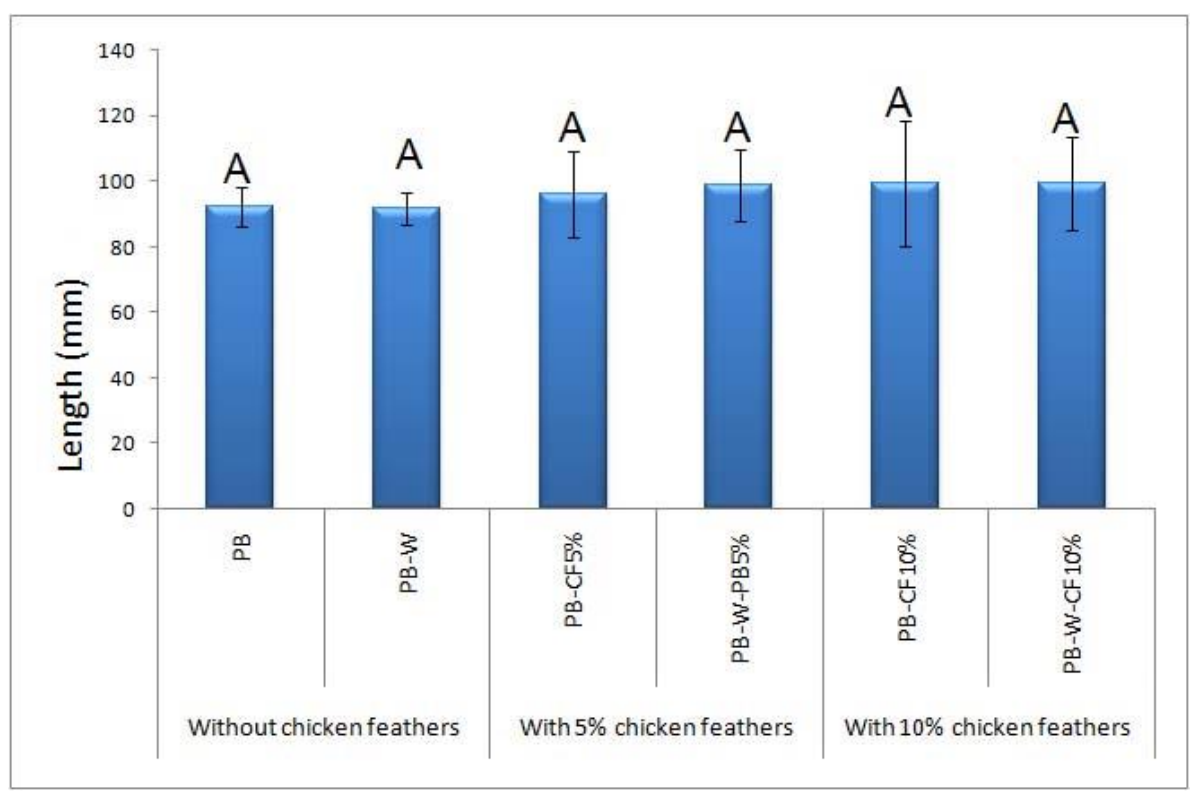

(A)

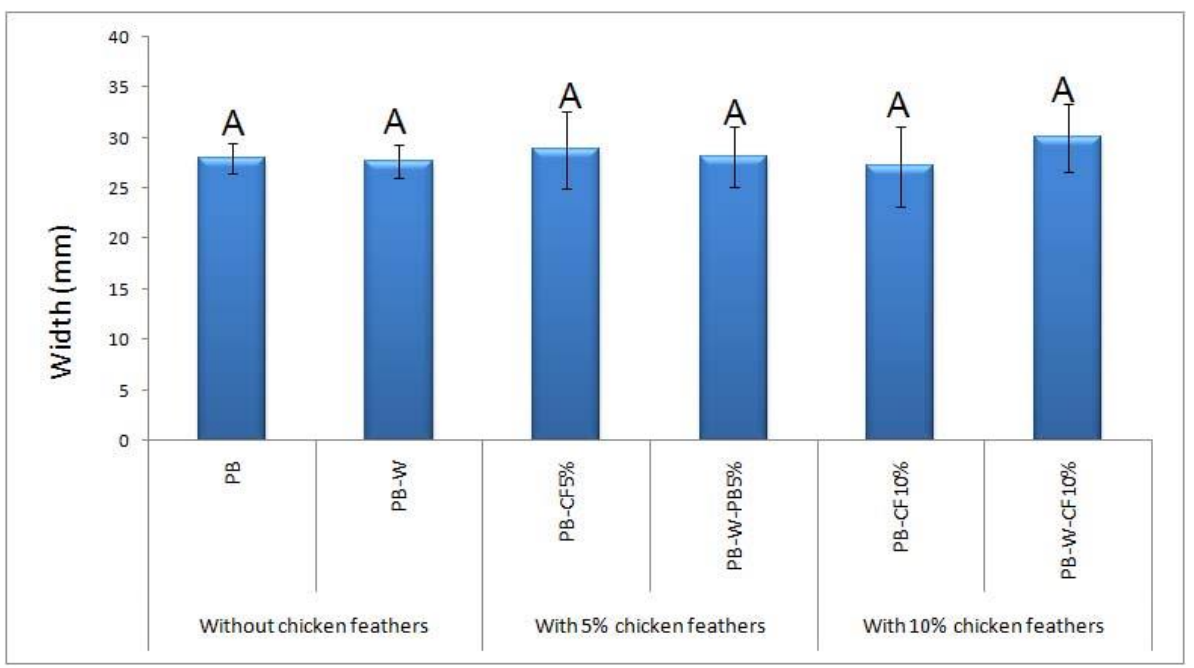

(B)

Figure 4. Length $(\mathbf{A})$ and width $(\mathbf{B})$ of the burnt area $(\mathrm{mm})$ after $120 \mathrm{~s}$ exposure to piloted fire, in six particleboard panels made from wood chips and the two chicken feather contents of $5 \%$ and $10 \%$, containing $10 \%$ wollastonite ( $\mathrm{PB}=$ particleboard panels; $\mathrm{W}=$ panels containing wollastonite; $\mathrm{CF}=$ chicken feather content) (letters on each column bar represent groupings based on Duncan's multiple range test, $\alpha=0.05)$.

Based on the five fire properties studied here (including the times to the onset of ignition and glowing, the duration of burning, and the length and width of the burnt area), a cluster analysis was performed (Figure 6). The dendrogram illustrated the close clustering of the control panels with no wollastonite and feather contents (PB panels) to the panels containing wollastonite and $5 \%$ of feathers (PB-W-CF5\%). However, the panels with $5 \%$ feathers and no wollastonite content were clustered quite remotely from the control panels (PB panels). This demonstrated the improving effect of wollastonite on the fire properties of panels that contained a low amount of feathers (i.e., $5 \%$ ). This indicates that wollastonite could positively mitigate the negative effects of the addition of feathers in the panels. The panels containing 10\% feathers (both with and without wollastonite) were remotely clustered from the control panels (PB panels), demonstratingthat the positive effects of the addition of $10 \%$ wollastonite to the resin could not mitigate the negative 
effects of the feathers on the flammability of panels. Still, the two panels with $10 \%$ feather content were distinctly clustered remotely from each other. This in turn indicates that wollastonite was effective in improving the fire properties in the panels, though the degree of effectiveness was not so high as to fully eliminate the negative effects of the $10 \%$ feather content on the flammability of panels. In a previous study on the physical and mechanical properties of MDF and particleboard panels containing 5\% and 10\% chicken feathers, it was reported that the $10 \%$ feather content significantly deteriorated the physical and mechanical properties to the extent that the addition of wollastonite could not mitigate the negative effects [21]. However, wollastonite was reported to successfully improve the physical and mechanical properties to acceptable levels in the panels containing $5 \%$ feathers.

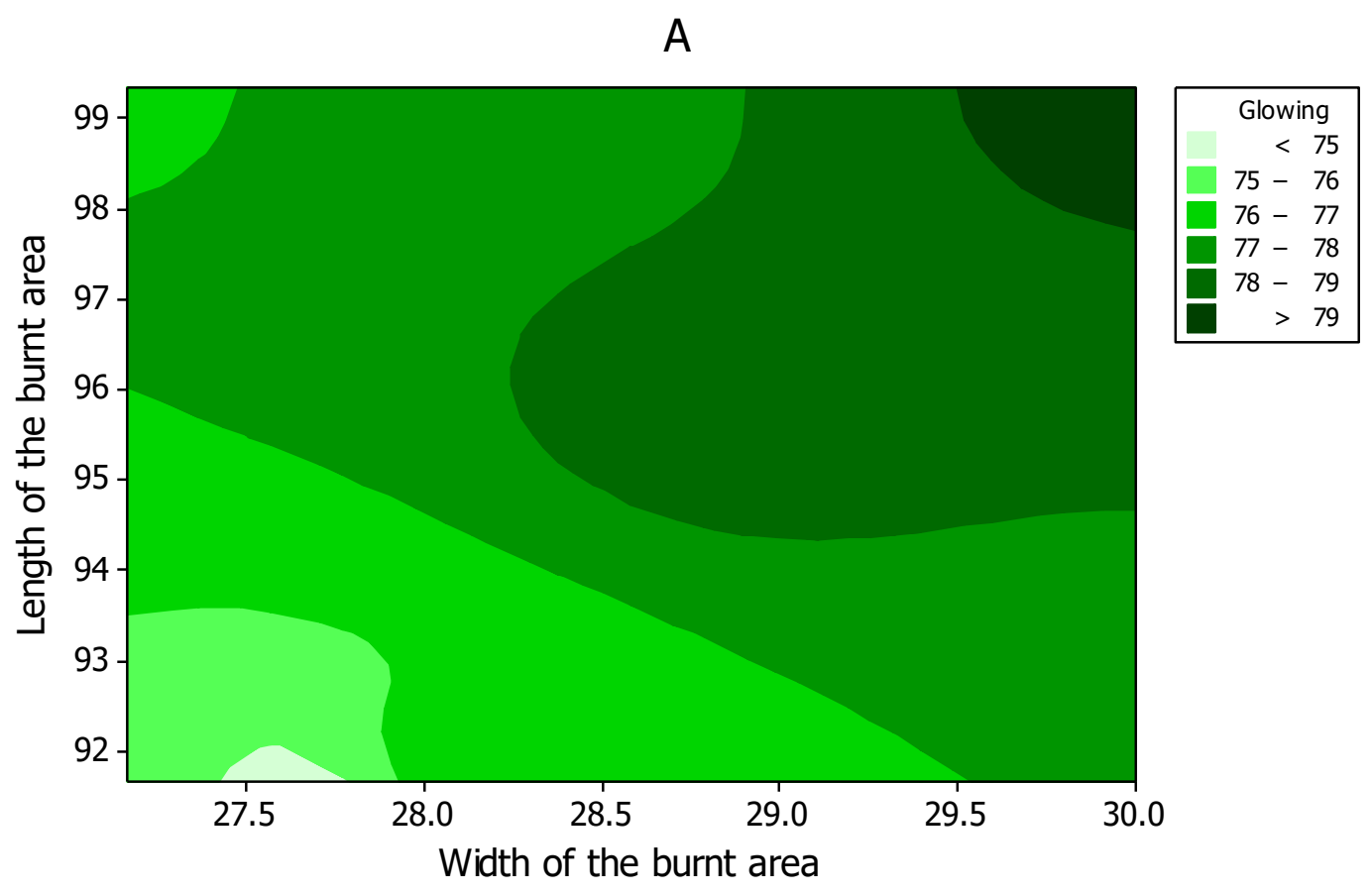

B

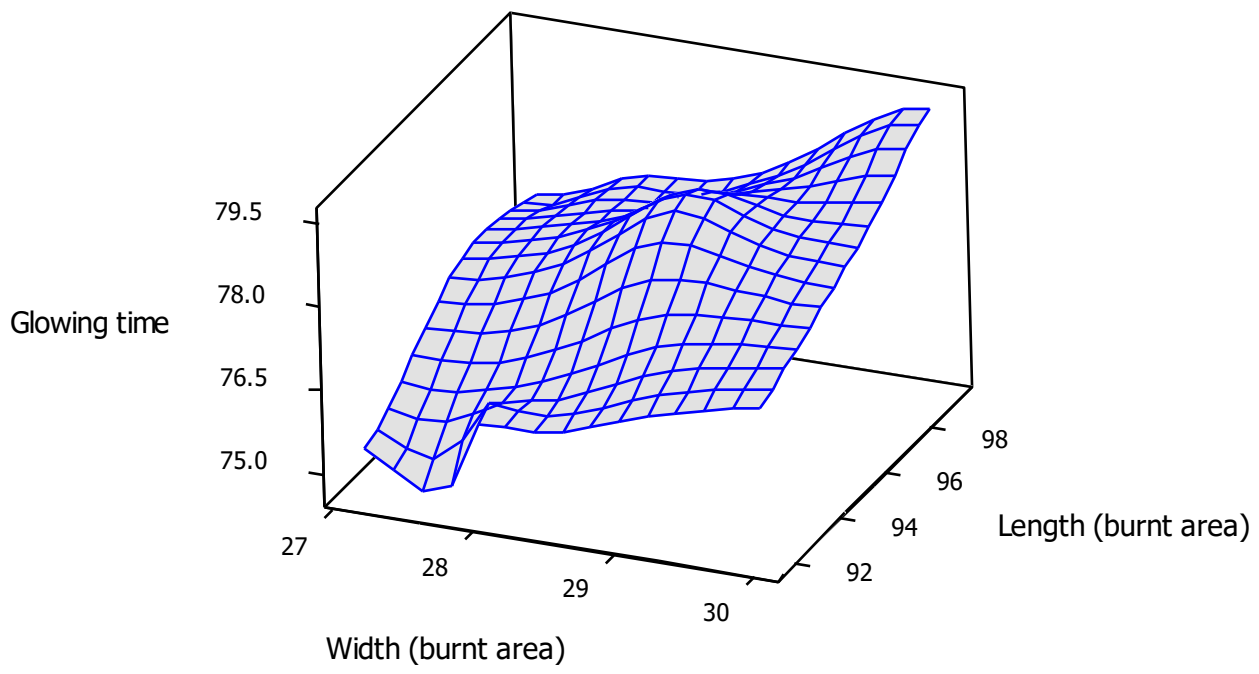

Figure 5. Contour (A) and surface (B) plots between the fire properties tested in the six particleboard panels made from wood chips and chicken feathers containing $10 \%$ wollastonite. 


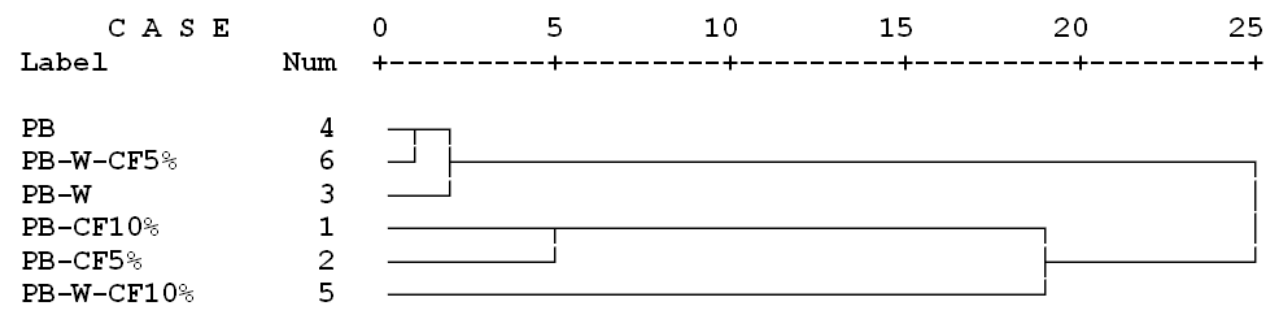

Figure 6. Cluster analysis of the six types of particleboard panels made from wood chips and chicken feathers and containing $10 \%$ wollastonite, based on the five fire properties $(\mathrm{PB}=$ particleboard; $\mathrm{W}=$ wollastonite; $\mathrm{CF}=$ chicken feather content).

Based on the tests and results of the abovementioned experiment, it was concluded thata $\%$ content of chicken feathers can be considered an optimum level, enough to meetpart of the ever-growing need for new sources of raw material in particleboard manufacturing factories, without sacrificing the important fire properties. Moreover, the addition of $10 \%$ wollastonite is recommended to significantly improve the fire properties, making the panels more secure in applications with higher risk of fire. However, achicken feather content of $10 \%$ is not recommended, as the results of this study suggest that it leads to a significant deterioration of all properties (including physical, mechanical, and fire properties).

\section{Conclusions}

The present study focused on the effects of the addition of $5 \%$ and $10 \%$ chicken feathers on the fire properties of particleboard panels. Moreover, separate panels were produced with $10 \%$ wollastonite to help mitigate the probable negative effects of the addition of chicken feathers. Results demonstrated a significant deterioration of the fire properties in the panels with $10 \%$ chicken feather content. The addition of wollastonite could not help mitigate the negative effects of the incompatibility of the feathers in panels with $10 \%$ feather content. It was concluded that particleboard panels with $10 \%$ chicken feathers were not acceptable. The chicken feather content of $5 \%$ seemed to be a good option to partially satisfy the ever-growing need for natural materials, and to keep the fire properties of panels at an acceptable level as well. The opposing effects of the addition of wollastonite on one side, and chicken feathers on the other side, resulted in no significant correlation between the fire properties. Alternative resin systems such as isocyanate resins and the application of other silicate materials may be an avenue for further exploration.

Author Contributions: Methodology, H.R.T., P.A. and A.N.P.; validation, H.R.T., H.M. and A.N.P.; investigation, H.R.T.; writing-original draft preparation, H.R.T., H.M. and A.N.P; writing-review and editing, H.R.T., H.M. and A.N.P.; visualization, H.R.T.; supervision, H.R.T. and A.N.P. All authors have read and agreed to the published version of the manuscript.

Funding: This research received no external funding.

Institutional Review Board Statement: Not applicable.

Informed Consent Statement: Not applicable.

Data Availability Statement: The data presented in this study are available on request from the corresponding author.

Acknowledgments: The first author appreciates the constant scientific support of Jack Norton (Retired, Horticulture \& Forestry Science, Queensland Department of Agriculture, Forestry and Fisheries, Australia).

Conflicts of Interest: The authors declare no conflict of interest. 


\section{References}

1. Singh, T.; Singh, A.P. A review on natural products as wood protectant. Wood Sci. Technol. 2012, 46, 851-870. [CrossRef]

2. Papadopoulos, A.N.; Avtzis, D.; Avtzis, N. The biological effectiveness of wood modified with linear chain carboxylic acid anhydrides against the subterranean termites Reticulitermes flavipes. Holz Roh Werkst. 2003, 66, 249-252. [CrossRef]

3. Papadopoulos, A.N.; Taghiyari, H.R. Innovative Wood Surface Treatments Based on Nanotechnology. Coatings 2019, 9, 886. [CrossRef]

4. Mantanis, G.; Papadopoulos, A.N. Reducing the thickness swelling of wood based panels by applying a nanotechnology compound. Eur. J. Wood Wood Prod. 2010, 68, 237-239. [CrossRef]

5. Taghiyari, H.R.; Norton, J.; Tajvidi, M. Effects of Nano-materials on Different Properties of Wood-Composite Materials-Chapter 14. In Bio-Based Wood Adhesives: Protection, Characterization, and Testing; CRC Press: Boca Raton, FL, USA, 2016.

6. Taghiyari, H.R.; Tajvidi, M.; Taghiyari, R.; Mantanis, G.I.; Esmailpour, A.; Hosseinpourpia, R. Nanotechnology for wood quality improvement and protection-Chapter 19. In Nanomaterials for Agriculture and Forestry Application; Elsevier: Amstedam, The Netherlands, 2020. [CrossRef]

7. White, R.H.; Dietenberger, M.A. Wood Handbook, Chapter 17: Fire Safety; Forest Products Laboratory; Gen. Tech. Rep. FPL-GTR-113; Department of Agriculture, Forest Service, Forest Products Laboratory: Madison, WI, USA, 1999; 463p.

8. Igaz, R.; Kristak, L.; Ruziak, I.; Gajtanska, M.; Kucerka, M. Thermophysical properties of OSB Boards versus Equilibrium Moisture Content. Bioresources 2017, 12, 8106-8118.

9. Taghiyari, H.R. Fire-Retarding Properties of Nano-Silver in Solid Woods. Wood Sci. Technol. 2012, 46, 939-952. [CrossRef]

10. Pizzi, A.; Papadopoulos, A.; Policardi, F. Wood Compositesand Their Polymer Binders. Polymers 2020, 12, 1115. [CrossRef] [PubMed]

11. Gašparík, M.; Osvaldová, L.; Čekovská, H.; Potůček, D. Flammability characteristics of thermally modified oak wood treated with a fire retardant. Bioresources 2017, 12, 8451-8467.

12. Winandy, J.E. Techline, Properties and Use of Wood, Composites, and Fiber Products, Durability of Fire-Retardant-Treated Wood; VL-5, Issued 01/98; United States Department of Agriculture, Forest Service, Forest Products Laboratory: Madison, WI, USA, 1998.

13. Taghiyari, H.R.; Esmailpour, A.; Majidi, R.; Morrell, J.J.; Mallaki, M.; Militz, H.; Papadopoulos, A.N. Potential use of wollatonite as a filler in UF resin based medium-density fiberboard (MDF). Polymers 2020, 12, 1435. [CrossRef]

14. Taghiyari, H.R.; Soltani, A.; Esmailpour, A.; Hassani, V.; Gholipour, H.; Papadopoulos, A.N. Improving Thermal Conductivity Coefficient in Oriented Strand Lumber (OSL) using Sepiolite. Nanomaterials 2020, 10, 599. [CrossRef]

15. Taghiyari, H.R.; Tajvidi, M.; Soltani, A.; Esmailpour, A.; Khodadoosti, G.; Jafarzadeh, H.; Militz, H.; Papadopoulos, A.N. Improving fire retardancy of unheated and heat-treated fir wood by nano-sepiolite. Eur. J. Wood Prod. 2021. [CrossRef]

16. Esmailpour, A.; Majidi, R.; Taghiyari, H.R.; Ganjkhani, M.; Mohseni, M.; Papadopoulos, A.N. Improving fire retardancy of beech wood by graphene. Polymers 2020, 12, 303. [CrossRef]

17. Maloney, T.M. Modern Particleboard and Dry Process Fibreboard Manufacturing; Hal Leonard Corporation: Milwaukee, WI, USA, 1993.

18. Walker, J.C.F. Primary Wood Processing: Principles and Practice; Springer: Dordrecht, The Netherlands, 2006.

19. Huuskonen, M.S.; Jarvisalo, J.; Koskinen, H.; Nickels, J.; Rasanen, J.; Asp, S. Preliminary results from a cohort of workers exposed to wollastonite in a Finish limestone quarry. Scand. J. Work. Health 1983, 9, 169-175. [CrossRef] [PubMed]

20. Huuskonen, M.S.; Tossavainen, A.; Koskinen, H.; Zitting, A.; Korhonen, O.; Nickels, J.; Korhonen, K.; Vaaranen, V. Wollastonite exposure and lung fibrosis. Environ. Res. 1983, 30, 291-304. [CrossRef]

21. Taghiyari, H.R.; Majidi, R.; Esmailpour, A.; Sarvari Samadi, Y.; Jahangiri, A.; Papadopoulos, A.N. Engineering composites made from wood and chicken feather bonded with UF resin fortified with wollastonite: A novel approach. Polymers 2020, $12,857$. [CrossRef]

22. Vakhitova, L.N. Fire retardant nanocoating for wood protection. In Nanotechnology in Eco-Efficient Construction; Woodhead Publishing: Cambridge, UK, 2019.

23. Wu, H.; La Parola, V.; Pantaleo, G.; Puleo, F.; Venezia, A.M.; Liotta, L.F. Ni-based catalysts for low temperature methane steam reforming: Recent results on Ni-Au and comparison with other bimetallic systems. Catalysts 2013, 3, 563-583. [CrossRef]

24. Weichelt, F.; Emmler, R.; Flyunt, R.; Beyer, E.; Buchmeiser, M.R.; Beyer, M. ZnO-Based UV Nanocomposites for Wood Coatings in Outdoor Applications. Macromol. Mater. Eng. 2010, 29, 130-136. [CrossRef]

25. Bueno, A.B.F.; Banon, M.V.N.; Morentín, L.; García, M.J.M. Treatment of natural woodveneers with nanooxides to improve their fire behaviour. In Proceedings of the 2nd International Conference on Structural Nano Composites, Madrid, Spain, 20-21 May 2014; Series: Materials Science and Engineering. Institute of Physics: Bristol, UK, 2014.

26. Malthig, B.; Swaboda, C.; Roessler, A.; Bottcher, H. Functionalising wood by nanosol application. J. Mater. Chem. 2008, 18, 3180-3192. [CrossRef]

27. Yeniocak, M.; Göktas, O.; Erdil, Y.Z.; Özen, E. Investigating the use of vine pruning stalks (Vitis Vinifera, L. CV. Sultani) as raw material for particleboard manufacturing. Wood Res. 2014, 59, 167-176.

28. Klimek, P.; Meinlschimidt, P.; Wimmer, R.; Plinke, B. Using sunflower (Helianthus annuus L.), topinambour (Helianthus tuberosus L.) and cup-plant (Silphium perfoliatum L.) stalks as alternative raw materials for particleboards. Ind. Crop. Prod. 2016, 92, 157-164. [CrossRef]

29. Nazerian, M.; Beyki, Z.; Gargari, R.; Kool, F. Theeffectofsometechnologicalproductionvariablesonmechanicalandphysicalpropertiesofparticl Maderas Cienc. Technol. 2016, 18, 167-178. 
30. Papadopoulos, A.N.; Hill, C.A.S.; Gkaraveli, A.; Ntalos, G.; Karastergiou, S. Bamboo chips (Bambusa vulgaris) as an alternative lignocellulosic raw material for particleboard manufacture. Holz Als Roh-Und Werkst. 2004, 62, 36-39. [CrossRef]

31. Papadopoulos, A.N.; Traboulay, E.; Hill, C.A.S. One layer Experimental Particleboard from Coconut Chips (Cocos nucifera L.). Holz Als Roh-Und Werkst. 2002, 60, 394-396. [CrossRef]

32. Kord, B.; Zare, H.; Hosseinzabeh, A. Evaluation of the mechanical and physical properties of particleboard manufactured from canola straws. Maderas Cienc. Technol. 2016, 18, 9-18. [CrossRef]

33. Küçüktüvek, M.; Kasal, A.; Kuşkun, T.; Erdil, Y. Utilizing poppy husk-based particleboards as an alternative material in case furniture construction. BioResources 2017, 12, 839-852. [CrossRef]

34. Li, X.; Cai, Z.; Winandy, J.; Basta, A. Selected properties of particleboard panels manufactured from rice straws of different geometries. Biores. Technol. 2010, 101, 4662-4666. [CrossRef]

35. Ntalos, G.A.; Grigoriou, A.H. Characterization and utilisation of vine prunings as a wood substitute for particleboard production. Ind. Crop. Prod. 2002, 16, 59-68. [CrossRef]

36. Tudor, E.M.; Dettendorfer, A.; Kain, G.; Barbu, M.C.; Réh, R.; Krišt'ák, L'. Sound-Absorption Coefficient of Bark-Based Insulation Panels. Polymers 2020, 12, 1012. [CrossRef]

37. Papadopoulos, A.N.; Hague, J.R.B. The potential use of Linum usitatissimun (flax) chips as a raw lignocellulosic material for particleboards. Ind. Crop. Prod. 2003, 17, 143-147. [CrossRef]

38. Papadopoulos, A.N. Banana chips (Musa acuminate) as an alternative lignocellulosic raw material for particleboard manufacture. Maderas Cienc. Technol. 2018, 20, 395-402.

39. Papadopoulos, A.N.; Kyzas, G.Z.; Mitropoulos, A.C. Lignocellulosic composites from acetylated sunflower stalks. Appl. Sci. 2019, 9, 646. [CrossRef]

40. Rammou, E.; Mitani, A.; Ntalos, G.; Koutsianitis, D.; Taghiyari, H.R.; Papadopoulos, A.N. The Potential Use of Seaweed (Posidonia oceanica) as an Alternative Lignocellulosic Raw Material for Wood Composites Manufacture. Coatings 2021, 11, 69. [CrossRef]

41. Kock, J.W. Physical and Mechanical Properties of Chicken Feather Materials. Master's Thesis, School of Civil Environmental Engineering, Georgia Institute of Technology, Atlanta, GA, USA, 2006.

42. Tesfaye, T.; Sithole, B.B.; Ramjugernath, D. Valorisation of chicken feathers: A review and recovery route-Current status and future prospects. Clean Technol. Environ. Policy 2017, 19, 2363-2378. [CrossRef]

43. Tesfaye, T.; Sithole, B.B.; Ramjugernath, D. Valorisation of chicken feathers: Recycling and recovery routes. In Proceedings of the Sardinia 2017-16th International Waste Management \& Landfill Symposium, Santa Margherita di Pula, Cagilari, Italy, 2-6 October 2017; p. 10.

44. Figueroa, M.; Bustos, C.; Dechent, P.; Reyes, L.; Cloutier, A.; Giuliano, M. Analysis of rheological and thermo-hygro-mechanical behaviour of stress-laminated timber bridge deck in variable environmental conditions. Maderas Cienc. Y Tecnol. 2012, 14, 303-319.

45. ISO 11925-3:1997. Cor. 1: 1998. Reaction to Fire Tests. Ignitability of Building Products Subjected to Direct Impingement of Flame. Part III: Multi-Source Test; BSI: London, UK, 1998; ISBN 0580292258.

46. Taghiyari, H.R.; Morrell, J.J.; Papadopoulos, A.N. Wollastonite to improve fire properties in medium-density fiberboard made from wood and chicken feather fibers. Appl. Sci. 2021, 11, 3070. [CrossRef]

47. Esmailpour, A.; Taghiyari, H.R.; Majidi, R.; Babaali, S.; Morrell, J.J.; Mohammadpanah, B. Effects of adsorption energy on air and liquid permeability of nanowollastonite-treated medium-density fiberboard. IEEE Trans. Instrum. Meas. 2021, 70. [CrossRef]

48. Taghiyari, H.R.; Majidi, R.; Mohseni Armaki, S.M.; Haghighatparast, M. Graphene as reinforcing filler in polyvinyl acetate resin. Int. J. Adhes. Adhes. 2021, accepted.

49. Hassani, V.; Taghiyari, H.R.; Schmidt, O.; Maleki, S.; Papadopoulos, A.N. Mechanical and physical properties of oriented strand lumber (OSL): The effect of fortification level of nanowollastonite on UF resin. Polymers 2019, 11, 1884. [CrossRef] [PubMed]

50. Esmailpour, A.; Taghiyari, H.R.; Nouri, P.; Jahangiri, A. Fire-retarding properties of nanowollastonite in particleboard. Fire Mater. 2018, 42, 306-315. [CrossRef] 